\title{
Synthesis, characterization, and thermal behavior of amidosulfonates of transition metals in air and nitrogen atmosphere
}

\author{
Jose Marques Luiz ${ }^{1+}$, Ronaldo Spezia Nunes ${ }^{1}$ (®) \\ 1. São Paulo State University (Unesp), School of Engineering, Department of Chemistry and Energy, Guaratinguetá, São Paulo, Brazil \\ +Corresponding author: Jose Marques Luiz, Phone: +55 12 31232170, Email address: jose-marques.luiz@unesp.br
}

\begin{tabular}{ll}
\hline ARTICLE INFO & Keywords: \\
Article history: & 1. sulfamic acid \\
Received: January 29,2020 & 2. thermal behavior \\
Accepted: May 11, 2020 & 3. sulfamates \\
Published: October 01,2020 & 4. transition metals
\end{tabular}

Published: October 01, 2020

\begin{abstract}
The amidosulfonates of $\mathrm{Mn}^{2+}$, $\mathrm{Co}^{2+}, \mathrm{Ni}^{2+}, \mathrm{Cu}^{2+}$ and $\mathrm{Zn}^{2+}$ were prepared by the direct reaction between the metal carbonate and the amidosulfonic acid with heating and stirring. The compounds were characterized by infrared absorption spectroscopy (IRFT), elemental analysis, thermal analysis (TG and DTA) and Xray diffraction by the powder method. The absorptions observed in IR spectra are associated with $\mathrm{N}-\mathrm{H}$ and $\mathrm{O}-\mathrm{H}$ stretching, as well as symmetrical and asymmetric S-O stretching in the sulfonic group. The compounds present Xray diffraction pattern with well-defined reflections, showing no evidence of isomorphism. The TG-DTA curves allowed to establish the stoichiometry of compounds as $\mathrm{M}\left(\mathrm{NH}_{2} \mathrm{SO}_{3}\right)_{2} \cdot \mathrm{xH}_{2} \mathrm{O}$, where $\mathrm{M}=\mathrm{Mn}^{2+}, \mathrm{Co}^{2+}$, $\mathrm{Ni}^{2+}, \mathrm{Cu}^{2+}$ and $\mathrm{Zn}^{2+}$ and $\mathrm{x}$ ranging from 1 to 4 .

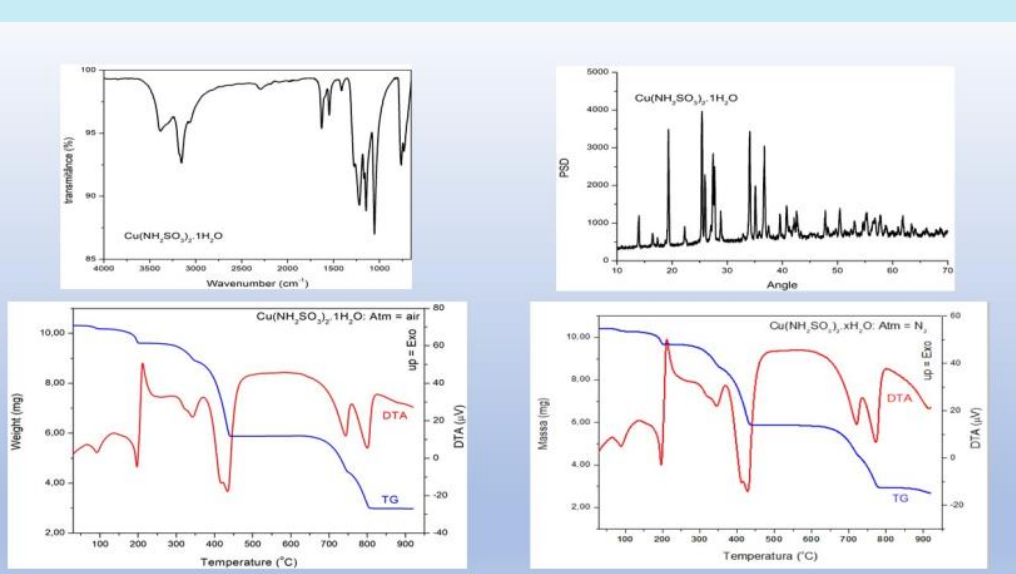

Characterization (IRFT, DRX) and thermal behavior (TG, DTA) of $\mathrm{Cu}\left(\mathrm{NH}_{2} \mathrm{SO}_{3}\right)_{2} \cdot 1 \mathrm{H}_{2} \mathrm{O}$

Dehydration leads to the formation of stable anhydrous. In all cases the respective sulfates are formed as an intermediate. After consecutive steps of decomposition, the respective oxides were obtained: $\mathrm{Mn}_{3} \mathrm{O}_{4}, \mathrm{CoO}, \mathrm{NiO}, \mathrm{CuO}$ and $\mathrm{ZnO}$. The TG-DTA curves are characteristic for each sample, with thermal events related to dehydration and ligand decomposition.
\end{abstract}

\section{Introduction}

The amidosulfonic acid or sulfamic acid $\left(\mathrm{NH}_{2} \mathrm{SO}_{3} \mathrm{H}\right)$ has molar mass $97.10 \mathrm{~g} \mathrm{~mol}^{-1}$. When dry it is stable, but in solution, it is easily hydrolyzed, forming ammonium bisulfate. It is relatively soluble in water, moderately soluble in alcohol, poorly soluble in acetone, insoluble in ether and very soluble in nitrogenous bases, liquid ammonia, pyridine, formamide and dimethylformamide. It is classified as a strong acid $\left(\mathrm{pH}=1.2\right.$ in $1 \%$ aqueous solution and $\left.25^{\circ} \mathrm{C}\right)$. It is used as standard in alkalimetry, in steel cleaning, in removal of nitrites and stabilization of chlorine in pool water. It is a toxic compound, used as poison for rats. Handling requires careful care as it easily irritates the skin and mucous membrane. It forms orthorhombic crystals and has melting point near $205{ }^{\circ} \mathrm{C}^{1}$. In recent years sulfamic acid has been used as an efficient heterogeneous catalyst in a series of organic reactions, such as acetylation, esterification, condensation, transesterification, among others ${ }^{2}$. It is a ZWITTERION, in other words, a dipolar ion having opposite charges on different atoms. In the formation of metal complexes, both amine and sulfonate groups participate in the coordination with the metal ion.

Few studies report the chemical and thermal properties of metal salts containing sulfonic acid derivatives, although the preparation of these salts 
is easy to perform ${ }^{3-10}$. Maksin and Standritchuk ${ }^{3}$ studied the water solubility of $\mathrm{Ni}(\mathrm{II})$ and $\mathrm{Co}(\mathrm{II})$ sulfamates. Budurov et al. ${ }^{4,5}$ studied by DSC the phase transformations that occur in the heating of some amidosulfonates, determining the energy involved in the processes represented by endothermic peaks. Also, by DSC, Thege ${ }^{6}$ investigated the thermal behavior of $\left(\mathrm{NH}_{4}\right)_{2} \mathrm{SO}_{4}$, $\mathrm{NH}_{4} \mathrm{HSO}_{4}$ and $\mathrm{NH}_{4} \mathrm{NH}_{2} \mathrm{SO}_{3}$. The crystalline structure and growth of $\mathrm{Li}\left[\mathrm{NH}_{2} \mathrm{SO}_{3}\right]$ monocrystals was studied by Stade, Held and Bohaty ${ }^{7}$, and it was possible to establish the spatial group, cell parameters and refractive index for the crystals obtained. The elastic properties of sulfamic acid and various sulfamates were studied by Haussül and Haussül and reported phase transformations ${ }^{8}$. Shimizau et al. ${ }^{9}$ determined the crystallographic properties of silver amidosulfonate and described a lamellar structure with potential chemical applications. Squattrito and coworkers studied the layered structures of metal salts of sulfonic acid derivatives ${ }^{10-12}$. Jaishree et al. ${ }^{13}$ studied the optical and thermal properties of a monocrystal of amidosulfonic acid and reported the absorption bands in the infrared region. The main absorptions were attributed to the vibrational modes of the $\mathrm{SO}_{3}{ }^{-}$and $-\mathrm{NH}_{3}{ }^{+}$group. Brahmaji et al. also identified the functional groups by FTIR and reported the changes observed in the pure crystals and doped with $\mathrm{Tb}^{3+}{ }^{14}$. Wickleder ${ }^{15}$ studied the synthesis, crystal structure, and thermal behavior of some rare earth amidosulfonates. Luiz, Nunes and Matos $^{16}$ studied the thermal behavior of all the amidosulfonates of the rare earth series and observed a mass gain between $250^{\circ} \mathrm{C}$ and $350^{\circ} \mathrm{C}$, attributed to an oxidative process $\mathrm{SO}_{3}{ }^{2-} \rightarrow \mathrm{SO}_{4}{ }^{2-}$, which is more evident in a lower heating rate. Brahmaji et al. ${ }^{14}$ also observed mass gain in this temperature range.

\section{Materials and Methods}

All chemicals used in this study were of analytical grade. Metallic chlorides were obtained from Sigma Aldrich, while the sodium hydrogen carbonate and silver nitrate were obtained from Merck and were used without further purification.

\subsection{Metal Carbonates}

Carbonates of $\mathrm{Mn}(\mathrm{II}), \mathrm{Co}(\mathrm{II}), \mathrm{Ni}(\mathrm{II}), \mathrm{Cu}(\mathrm{II})$ and $\mathrm{Zn}(\mathrm{II})$ were prepared by adding slowly, with continuous stirring, a saturated sodium hydrogen carbonate solution to aqueous solutions metal chloride, until total precipitation of the metal ions. The precipitates were washed with distilled water until the elimination of chloride ions (qualitative test with $\mathrm{AgNO}_{3} / \mathrm{HNO}_{3}$ solution for chloride) and was placed in vacuum desiccator until constant mass.

\subsection{Metal Amidosulfonates}

The compounds were prepared by the direct reaction between the aqueous suspension of the metal carbonates ( $\mathrm{Mn}, \mathrm{Co}, \mathrm{Ni}, \mathrm{Cu}$ and $\mathrm{Zn}$ ) and the amidosulfonic acid, with heating at $80{ }^{\circ} \mathrm{C}$ and stirring. The acid in powder form was slowly added until a small amount of the metal carbonate remained. The carbonate in excess was removed by filtration and the aqueous solution was evaporated slowly near to dryness. Subsequently, the solution was kept in vacuum desiccator until constant mass.

\subsection{Characterization of samples}

The infrared spectroscopy for amidosulfonic acid and its metal amidosulfonates were run on a Perkin-Elmer Spectrum 100 ATR FTIR spectrophotometer using ATR accessory with germanium crystal. The FTIR spectra were recorded with 16 scans per spectrum a resolution of $4 \mathrm{~cm}^{-1}$.

The X-ray powder patterns were obtained by using a BRUKER System D8 Advance Diffractometer, employing $\mathrm{CuK} \alpha$ radiation $(\lambda=$ $1.541 \AA), 25 \mathrm{~mA}, 40 \mathrm{kV}, 10 \mathrm{rpm}$ rotation, 0.02 step, 0.6 slit $\mathrm{mm}$, time $0.3 \mathrm{~s}$, in the range $2 \theta$ from 10 to 70 degrees. Elemental analysis for $\mathrm{H}, \mathrm{N}$ and $\mathrm{S}$ was performed using a Leco CHNS Analyzer.

The thermal behavior was evaluated by thermogravimetry (TG) and differential thermal analysis (DTA) in the simultaneous module TGDTA 6200 Extar 6000 from Seiko SII, with sample mass of the order of 3 to $10 \mathrm{mg}$, heating ratio $B=20{ }^{\circ} \mathrm{C} \min ^{-1}$ (30 to $900{ }^{\circ} \mathrm{C}$ ), alumina crucible, dynamic atmosphere of synthetic air and nitrogen, with flow of $100 \mathrm{~mL} \mathrm{~min}^{-1}$. As reference for DTA, previously calcined alumina was used. 


\section{Results and discussion}

The elemental analysis results are presented in Tab. 1 and are in agreement with the proposed general formula $\mathrm{M}\left(\mathrm{NH}_{2} \mathrm{SO}_{3}\right)_{2} \cdot \mathrm{xH}_{2} \mathrm{O}$, where $\mathrm{M}=$
$\mathrm{Mn}^{2+}, \mathrm{Co}^{2+}, \mathrm{Ni}^{2+}, \mathrm{Cu}^{2+}$ and $\mathrm{Zn}^{2+}$ and $\mathrm{x}$ the number of water molecules ranging from 1 to 4 , where $\mathrm{x}=$ 4 for $\mathrm{Mn}^{2+}, 3$ for $\mathrm{Co}^{2+}$ and $\mathrm{Zn}^{2+}, 2$ for $\mathrm{Ni}^{2+}$ and 1 for $\mathrm{Cu}^{2+}$.

Table 1. Elemental analysis of the solid compounds.

\begin{tabular}{|c|c|c|c|c|c|c|}
\hline \multirow{2}{*}{ Compound } & \multicolumn{2}{|c|}{$\%$ N } & \multicolumn{2}{c|}{$\% \mathbf{H}$} & \multicolumn{2}{c|}{$\% \mathrm{~S}$} \\
\cline { 2 - 7 } & Calc. & EA & Calc. & EA & Calc. & EA \\
\hline $\mathrm{Mn}\left(\mathrm{NH}_{2} \mathrm{SO}_{3}\right)_{2} .4 \mathrm{H}_{2} \mathrm{O}$ & 8.78 & 8.77 & 3.80 & 3.79 & 20.10 & 20.08 \\
\hline $\mathrm{Co}\left(\mathrm{NH}_{2} \mathrm{SO}_{3}\right)_{2} .3 \mathrm{H}_{2} \mathrm{O}$ & 9.18 & 9.31 & 3.30 & 3.54 & 20.01 & 21.30 \\
\hline $\mathrm{Ni}\left(\mathrm{NH}_{2} \mathrm{SO}_{3}\right)_{2} .2 \mathrm{H}_{2} \mathrm{O}$ & 9.76 & 9.63 & 2.81 & 2.78 & 22.36 & 22.04 \\
\hline $\mathrm{Cu}\left(\mathrm{NH}_{2} \mathrm{SO}_{3}\right)_{2} .1 \mathrm{H}_{2} \mathrm{O}$ & 10.24 & 10.20 & 2.21 & 2.21 & 23.43 & 23.35 \\
\hline $\mathrm{Zn}\left(\mathrm{NH}_{2} \mathrm{SO}_{3}\right)_{2} .3 \mathrm{H}_{2} \mathrm{O}$ & 8.99 & 9.08 & 3.24 & 3.27 & 20.58 & 20.78 \\
\hline
\end{tabular}

The main infrared absorption bands were associated with the $\mathrm{N}-\mathrm{H}$ stretching, namely, a $\mathrm{NH}_{3}{ }^{+}$broad band at $3400-3300 \mathrm{~cm}^{-1}$, the $\mathrm{N}-\mathrm{H}$ stretching as a weak band at $2873 \mathrm{~cm}^{-1}$ and the absorptions observed at 1533 and $1433 \mathrm{~cm}^{-1}$ due to symmetric stretching mode of $\mathrm{NH}_{3}{ }^{+}$while at $1567 \mathrm{~cm}^{-1}$ is due to asymmetric mode. The $\mathrm{SO}_{3}{ }^{-}$ stretching vibration was observed in a $1065 \mathrm{~cm}^{-1}$ and at $685 \mathrm{~cm}^{-1}$, the N-S stretching mode can be seen, all these absorptions agree with the literature $^{4-14}$. The absence of that weak band of $\mathrm{N}$ $\mathrm{H}$ stretching is an evidence that de coordination of the metal ions occurred by $\mathrm{NH}_{3}{ }^{+}$group. Another fact is the increase observed in the wavenumber for the N-S stretching, suggesting that the N-S bond becomes strongest. The vibrational spectra in the infrared region of amidosulfonic acid and metal amidosulfonates are show in the Fig. 1.

The X-ray powder pattern of the metal amidosulfonates are shown in the Fig. 2. The Xray diffractograms indicate that the compounds were obtained with a certain crystallinity degree, showing no evidence of isomorphism. The compounds showed low relative intensity $\left(\mathrm{I}_{\mathrm{o}}\right)$ reflections: $\mathrm{Mn}\left(2 \theta=19.0 ; \mathrm{I}_{\mathrm{o}}=845\right)$; Co $(2 \theta=$ 19.3; $\left.\mathrm{I}_{\mathrm{o}}=3621\right) ; \mathrm{Ni}\left(2 \theta=26.3 ; \mathrm{I}_{\mathrm{o}}=6534\right) ; \mathrm{Cu}(2 \theta$ $\left.=25.4 ; \mathrm{I}_{\mathrm{o}}=4010\right) ; \mathrm{Zn}\left(2 \theta=19.4 ; \mathrm{I}_{\mathrm{o}}=4146\right)$.

By the TG/DTA curves it was possible to establish the stoichiometry of the compounds, such as: $\mathrm{ML}_{2} \cdot \mathrm{XH}_{2} \mathrm{O}$, where $\mathrm{M}$ represents the metallic ions $\mathrm{M}=\mathrm{Mn}^{2+}, \mathrm{Co}^{2+}, \mathrm{Ni}^{2+}, \mathrm{Cu}^{2+}$ and $\mathrm{Zn}^{2+}$; $\mathrm{L}$ represents the anion $\mathrm{NH}_{2} \mathrm{SO}_{3}{ }^{-}$and $\mathrm{x}$ the number of water molecules ranging from 1 to 4 , where $\mathrm{x}=$ 4 for $\mathrm{Mn}^{2+}, 3$ for $\mathrm{Co}^{2+}$ and $\mathrm{Zn}^{2+}, 2$ for $\mathrm{Ni}^{2+}$ and 1 for $\mathrm{Cu}^{2+}$. In a synthetic air atmosphere, the events associated with the thermal decomposition of the ligand occur at slightly lower temperatures than in a nitrogen atmosphere. Tables 2 and 3 show the results extracted from the TG and DTA curves in the atmosphere of synthetic air and nitrogen. Figures 3 and 4 show the TG and DTA curves in the atmosphere of synthetic air and nitrogen, respectively.

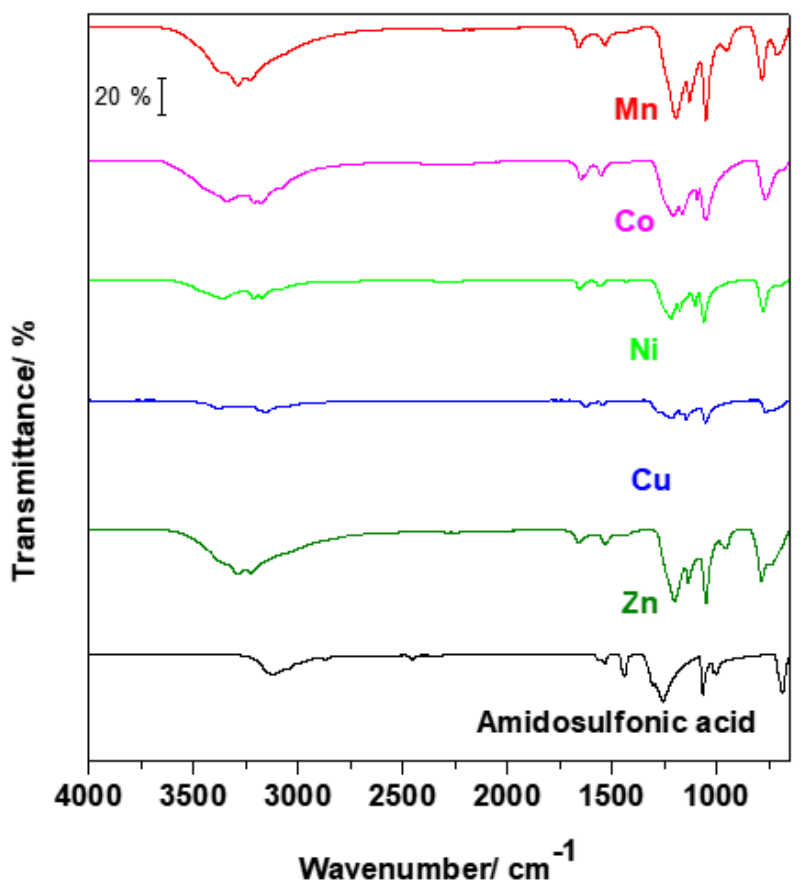

Figure 1. Vibrational spectra in the infrared region of amidosulfonic acid and metal amidosulfonates. 


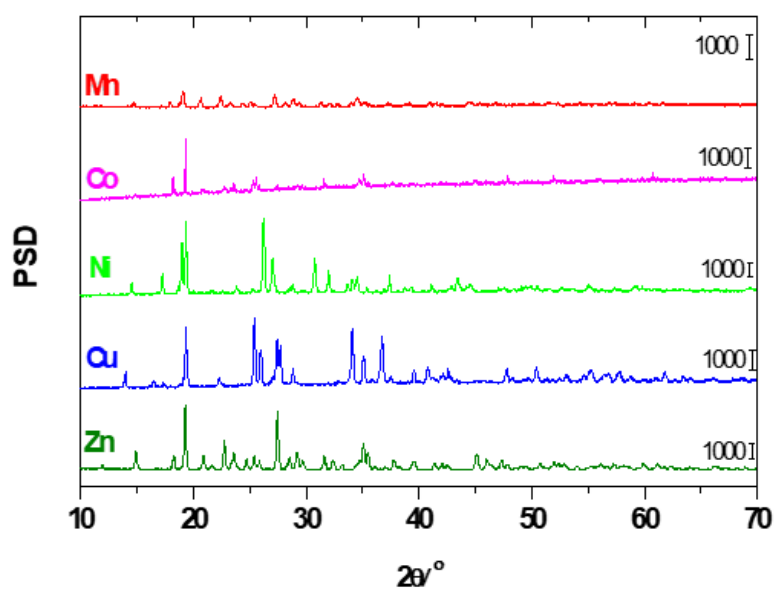

Figure 2. X-ray diffraction pattern of the metal amidosulfonates.

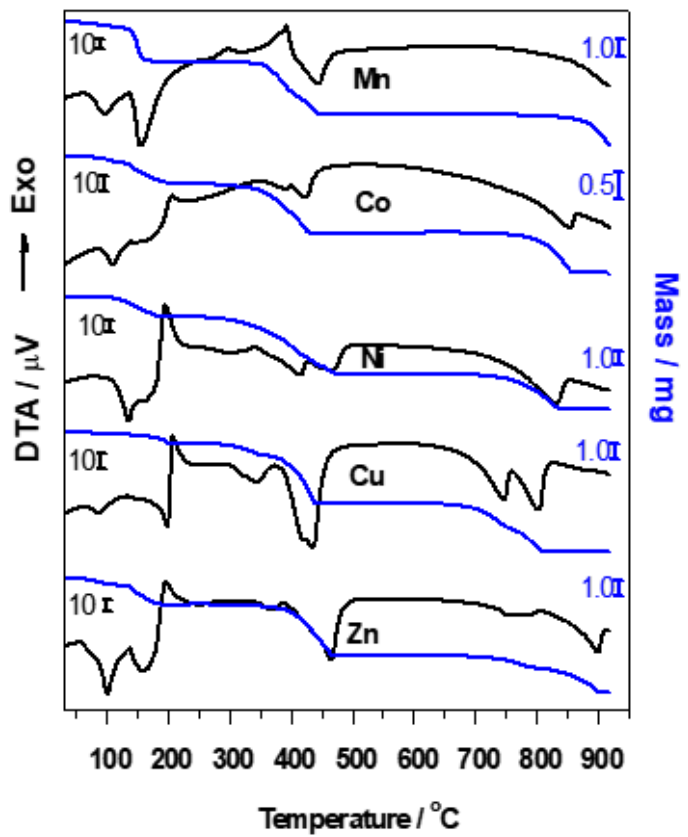

Figure 3. TG and DTA curves of the obtained compounds, in a synthetic air atmosphere. Sample mass: $\mathrm{Mn}=9.680 \mathrm{mg}, \mathrm{Co}=2.980 \mathrm{mg}, \mathrm{Ni}=10.194$ $\mathrm{mg}, \mathrm{Cu}=10.314 \mathrm{mg}$ and $\mathrm{Zn}=10.064 \mathrm{mg}$.

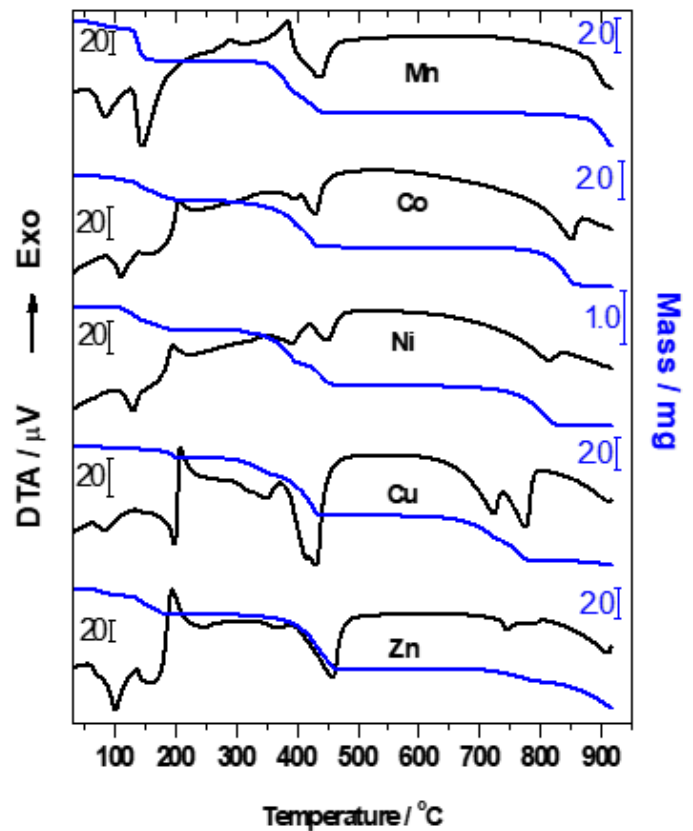

Figure 4. TG and DTA curves of the obtained compounds, in a nitrogen atmosphere. Sample mass: $\mathrm{Mn}=10.383 \mathrm{mg}, \mathrm{Co}=3,794 \mathrm{mg}, \mathrm{Ni}=2,984$ $\mathrm{mg}, \mathrm{Cu}=10.414 \mathrm{mg}$ and $\mathrm{Zn}=10.193 \mathrm{mg}$.

Table 2. Results extracted from the TG curves.

\begin{tabular}{|c|c|c|c|c|c|c|c|c|c|}
\hline \multirow{2}{*}{ Samples } & \multicolumn{2}{|c|}{ Molar mass / $\mathrm{g} \mathrm{mol}^{-1}$} & \multicolumn{2}{|c|}{ Metal / \% } & \multicolumn{2}{|c|}{$\mathrm{H}_{2} \mathrm{O} / \%$} & \multicolumn{3}{|c|}{ Residue / \% } \\
\hline & Calc. & $T G$ & Calc. & $T G$ & Calc. & $T G$ & Calc. & $T G$ & Oxide \\
\hline $\begin{array}{l}\mathrm{Mn}(\mathrm{L})_{2} \cdot 4 \mathrm{H}_{2} \mathrm{O}(\text { air }) \\
\mathrm{Mn}(\mathrm{L})_{2} .4 \mathrm{H}_{2} \mathrm{O}\left(\mathrm{N}_{2}\right)\end{array}$ & 319.17 & $\begin{array}{l}318.99 \\
319.90\end{array}$ & 17.21 & $\begin{array}{l}17.22 \\
17.17\end{array}$ & 22.57 & $\begin{array}{l}22.58 \\
22.75\end{array}$ & $?$ & $\begin{array}{l}? \\
?\end{array}$ & $\mathrm{Mn}_{3} \mathrm{O}_{4}$ \\
\hline $\begin{array}{l}\mathrm{Co}(\mathrm{L})_{2} .3 \mathrm{H}_{2} \mathrm{O}(\text { air }) \\
\mathrm{Co}(\mathrm{L})_{2} .3 \mathrm{H}_{2} \mathrm{O}\left(\mathrm{N}_{2}\right)\end{array}$ & 305.14 & $\begin{array}{l}301.35 \\
300.79\end{array}$ & 19.31 & $\begin{array}{l}19.56 \\
19.59\end{array}$ & 17.71 & $\begin{array}{l}16.67 \\
16.52\end{array}$ & 24.56 & $\begin{array}{l}24.86 \\
24.91\end{array}$ & $\mathrm{CoO}$ \\
\hline $\begin{array}{l}\mathrm{Ni}(\mathrm{L})_{2} .2 \mathrm{H}_{2} \mathrm{O} \text { (air) } \\
\mathrm{Ni}(\mathrm{L})_{2} .2 \mathrm{H}_{2} \mathrm{O}\left(\mathrm{N}_{2}\right)\end{array}$ & 286.90 & $\begin{array}{l}290.40 \\
291.72\end{array}$ & 20.46 & $\begin{array}{l}20.21 \\
20.11\end{array}$ & 12.55 & $\begin{array}{l}13.61 \\
14.00\end{array}$ & 26.03 & $\begin{array}{l}25.77 \\
25.60\end{array}$ & $\mathrm{NiO}$ \\
\hline $\begin{array}{l}\mathrm{Cu}(\mathrm{L})_{2} \cdot 1 \mathrm{H}_{2} \mathrm{O}(\text { air }) \\
\mathrm{Cu}(\mathrm{L})_{2} \cdot 1 \mathrm{H}_{2} \mathrm{O}\left(\mathrm{N}_{2}\right)\end{array}$ & 273.75 & $\begin{array}{l}274.58 \\
274.81\end{array}$ & 23.21 & $\begin{array}{l}23.15 \\
23.13\end{array}$ & 6.58 & $\begin{array}{l}6.86 \\
6.94\end{array}$ & 29.06 & $\begin{array}{l}28.93 \\
28.95\end{array}$ & $\mathrm{CuO}$ \\
\hline $\begin{array}{l}\mathrm{Zn}(\mathrm{L})_{2} .3 \mathrm{H}_{2} \mathrm{O} \text { (air) } \\
\mathrm{Zn}(\mathrm{L})_{2} .3 \mathrm{H}_{2} \mathrm{O}\left(\mathrm{N}_{2}\right)\end{array}$ & 311.61 & $\begin{array}{l}309.07 \\
308.32\end{array}$ & 20.98 & $\begin{array}{l}21.16 \\
21.21\end{array}$ & 17.34 & $\begin{array}{l}17.66 \\
16.46\end{array}$ & 26.12 & $\begin{array}{c}26.33 \\
?\end{array}$ & $\mathrm{ZnO}$ \\
\hline
\end{tabular}


Table 3. Results extracted from the DTA curves.

\begin{tabular}{|c|c|c|c|c|c|c|c|c|c|}
\hline \multirow{2}{*}{ Samples } & \multicolumn{9}{|c|}{ DTA Peak (Tp) $/{ }^{\circ} \mathrm{C}$} \\
\hline & endo & endo & exo & exo & endo & endo & endo & endo & endo \\
\hline $\mathrm{Mn}\left(\mathrm{L}_{2}\right) \cdot 4 \mathrm{H}_{2} \mathrm{O}$ (air) & 89.59 & 148.4 & 289.0 & 387.2 & 439.4 & 671.3 & 874.0 & & \\
\hline $\mathrm{Mn}\left(\mathrm{L}_{2}\right)_{2} \cdot 4 \mathrm{H}_{2} \mathrm{O}\left(\mathrm{N}_{2}\right)$ & 84.64 & 146.8 & 289.0 & 383.8 & 439.4 & 699.4 & 872.8 & & \\
\hline $\mathrm{Co}(\mathrm{L})_{2} .3 \mathrm{H}_{2} \mathrm{O}$ (air) & 112.4 & 156.5 & 210.5 & & 392.0 & 426.4 & 854.8 & & \\
\hline $\mathrm{Co}(\mathrm{L})_{2} .3 \mathrm{H}_{2} \mathrm{O}\left(\mathrm{N}_{2}\right)$ & 110.8 & 164.8 & 209.0 & & 400.2 & 432.9 & 853.2 & & \\
\hline $\mathrm{Ni}(\mathrm{L})_{2} \cdot 2 \mathrm{H}_{2} \mathrm{O}$ (air) & 133.9 & 164.2 & 203.0 & & 303.4 & 411.3 & 462.0 & 824.1 & \\
\hline $\mathrm{Ni}(\mathrm{L})_{2} \cdot 2 \mathrm{H}_{2} \mathrm{O}\left(\mathrm{N}_{2}\right)$ & 132.0 & & 200.7 & & 323.6 & 395.3 & 450.0 & 814.0 & \\
\hline $\mathrm{Cu}(\mathrm{L})_{2} .1 \mathrm{H}_{2} \mathrm{O}$ (air) & 89.60 & 195.9 & 210.5 & & 343.0 & 419.8 & 436.2 & 741.9 & 799.1 \\
\hline $\mathrm{Cu}(\mathrm{L})_{2} \cdot 1 \mathrm{H}_{2} \mathrm{O}\left(\mathrm{N}_{2}\right)$ & 89.60 & 195.9 & 212.4 & & 344.6 & 411.7 & 426.4 & 719.2 & 773.0 \\
\hline $\mathrm{Zn}(\mathrm{L})_{2} \cdot 3 \mathrm{H}_{2} \mathrm{O}$ (air) & 97.10 & 162.1 & 203.0 & & 364.2 & 457.4 & 804.2 & 900.0 & \\
\hline $\mathrm{Zn}(\mathrm{L})_{2} \cdot 3 \mathrm{H}_{2} \mathrm{O}\left(\mathrm{N}_{2}\right)$ & 97.10 & 164.8 & 201.6 & & 364.2 & 465.4 & 789.4 & 912.0 & \\
\hline
\end{tabular}

\section{$3.1 \mathrm{Mn}\left(\mathrm{NH}_{2} \mathrm{SO}_{3}\right)_{2} .4 \mathrm{H}_{2} \mathrm{O}$}

Dehydration of the manganese (II) amidosulfonate occurs in two consecutive steps with the elimination of one and subsequently three water molecules, between 30 and $220{ }^{\circ} \mathrm{C}$, with mass loss about $22 \%$. In this step two endothermic peaks are observed at $90{ }^{\circ} \mathrm{C}$ and $148^{\circ} \mathrm{C}$ (synthetic air) at $85^{\circ} \mathrm{C}$ and $147{ }^{\circ} \mathrm{C}\left(\mathrm{N}_{2}\right)$. The anhydrous compound remains stable between $219^{\circ} \mathrm{C}$ and $340^{\circ} \mathrm{C}$ (synthetic air) and between 197 ${ }^{\circ} \mathrm{C}$ and $333{ }^{\circ} \mathrm{C}\left(\mathrm{N}_{2}\right)$. Although no mass change was observed in this temperature range, there is an exothermic peak at $289{ }^{\circ} \mathrm{C}$ (synthetic air and $\mathrm{N}_{2}$ ) which may be associated with a crystallization process. Brahmaji et al. ${ }^{14}$ also reported a gain mass in this range temperature, however this thermal event needs to be further investigated. Budurov et $a l .{ }^{5}$ reported endothermic peaks attributed to phase transition at $177{ }^{\circ} \mathrm{C}$ $\left(\mathrm{KNH}_{2} \mathrm{SO}_{3}\right)$ and $182{ }^{\circ} \mathrm{C}\left(\mathrm{NaNH}_{2} \mathrm{SO}_{3}\right)$. Haussühl and Haussühl ${ }^{8}$ also detected phase transformation in $\mathrm{CsNH}_{2} \mathrm{SO}_{3}$.

The thermal decomposition of the compounds occurs in two distinct steps. The first step begins with an exothermic $\left(386^{\circ} \mathrm{C}\right)$ process followed by another endotherm $\left(439{ }^{\circ} \mathrm{C}\right)$ at both atmospheres. This stage leads to the formation of an intermediate, stable over a wide temperature range: $450{ }^{\circ} \mathrm{C}$ to $800{ }^{\circ} \mathrm{C}$ (synthetic air) and $443{ }^{\circ} \mathrm{C}$ and $820{ }^{\circ} \mathrm{C}\left(\mathrm{N}_{2}\right)$. This intermediate is probably $\mathrm{MnSO}_{4}($ Calc. $=47.31 \%, \mathrm{TG}=47.34 \%)$, that begins to decompose with an endothermic event $\left(850{ }^{\circ} \mathrm{C}\right)$ to produce the oxide. In the temperature range in which the experiments were performed $\left(30{ }^{\circ} \mathrm{C} \rightarrow 900{ }^{\circ} \mathrm{C}\right)$ the formation of the residual oxide could not be observed.

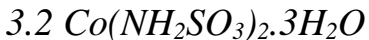

The dehydration process of the cobalt (II) amidosulfonate occurs in a single step, with simultaneous elimination of three water molecules between 85 and $220{ }^{\circ} \mathrm{C}$ and loss of mass of $16.6 \%$. In this stage two endothermic peak are observed around $112{ }^{\circ} \mathrm{C}$ and $157^{\circ} \mathrm{C}$ (synthetic air) and $111{ }^{\circ} \mathrm{C}$ and $164^{\circ} \mathrm{C}\left(\mathrm{N}_{2}\right)$. After the anhydrous formation, an exothermic peak is observed around $210{ }^{\circ} \mathrm{C}$, which may be associated with a crystallization process. The decomposition of the ligand occurs in two distinct stages: between $245^{\circ} \mathrm{C}$ and $450{ }^{\circ} \mathrm{C}$ (synthetic air) and between 258 ${ }^{\circ} \mathrm{C}$ and $442{ }^{\circ} \mathrm{C}\left(\mathrm{N}_{2}\right)$, both with formation of the $\mathrm{CoSO}_{4}$ intermediate. In this step two endothermic DTA peaks are observed: $392{ }^{\circ} \mathrm{C}$ and $426{ }^{\circ} \mathrm{C}$ (synthetic air) and $400{ }^{\circ} \mathrm{C}$ and $433{ }^{\circ} \mathrm{C}\left(\mathrm{N}_{2}\right)$. The $\mathrm{CoSO}_{4}$ intermediate $($ Calc. $=50.80 \%, \mathrm{TG}=51.80$ $\%)$ remains stable over a wide temperature range: between $442{ }^{\circ} \mathrm{C}$ and $720{ }^{\circ} \mathrm{C}$ (synthetic air) and between $450{ }^{\circ} \mathrm{C}$ and $716^{\circ} \mathrm{C}\left(\mathrm{N}_{2}\right)$. The formation of the residue occurs at $861{ }^{\circ} \mathrm{C}$, with mass loss of the order of $26 \%$, compatible with the formation of $\mathrm{CoO}$, in both atmospheres.

\section{$3.3 \mathrm{Ni}\left(\mathrm{NH}_{2} \mathrm{SO}_{3}\right)_{2} .2 \mathrm{H}_{2} \mathrm{O}$}

The dehydration of the nickel (II) amidosulfonate occurs in a two overlapping steps, with elimination of two water molecules between 90 and $192{ }^{\circ} \mathrm{C}$ (synthetic air) between $100{ }^{\circ} \mathrm{C}$ and $206{ }^{\circ} \mathrm{C}\left(\mathrm{N}_{2}\right)$ with mass loss of order of $13.5 \%$. At this stage, endothermic peaks are observed at 134 ${ }^{\circ} \mathrm{C}$ and $164{ }^{\circ} \mathrm{C}$ (synthetic air) and $132{ }^{\circ} \mathrm{C}\left(\mathrm{N}_{2}\right)$. After the anhydrous formation, an intense exothermic peak is observed at $203{ }^{\circ} \mathrm{C}$ (synthetic 
air) and $201{ }^{\circ} \mathrm{C}\left(\mathrm{N}_{2}\right)$ of low intensity, which may be associated with a crystallization process. The decomposition of the ligand occurs in two distinct stages: between $251^{\circ} \mathrm{C}$ and $479{ }^{\circ} \mathrm{C}$ (synthetic air) and between $294{ }^{\circ} \mathrm{C}$ and $461{ }^{\circ} \mathrm{C}\left(\mathrm{N}_{2}\right)$, both with formation of the $\mathrm{NiSO}_{4}$ intermediate. In this stage endothermic DTA peaks are observed at: $304{ }^{\circ} \mathrm{C}$, $411^{\circ} \mathrm{C}$ and $462{ }^{\circ} \mathrm{C}$ (synthetic air) and $324^{\circ} \mathrm{C}, 395$ ${ }^{\circ} \mathrm{C}$ and $450{ }^{\circ} \mathrm{C}\left(\mathrm{N}_{2}\right)$. The $\mathrm{NiSO}_{4}$ intermediate (Calc. $=53.94 \%, \mathrm{TG}=53.30 \%$ ) remains stable over a wide temperature range: between $474{ }^{\circ} \mathrm{C}$ and $720{ }^{\circ} \mathrm{C}$ (synthetic air) and between $459^{\circ} \mathrm{C}$ and $716{ }^{\circ} \mathrm{C}\left(\mathrm{N}_{2}\right)$. The formation of the residue occurs at $831{ }^{\circ} \mathrm{C}$ (synthetic air and $\mathrm{N}_{2}$ ) with loss mass in the order of $26 \%$, compatible with the formation of $\mathrm{NiO}$, in both atmospheres.

\section{$3.4 \mathrm{Cu}\left(\mathrm{NH}_{2} \mathrm{SO}_{3}\right)_{2} \cdot 1 \mathrm{H}_{2} \mathrm{O}$}

The dehydration of the copper (II) amidosulfonate occurs in a two overlapping steps, eliminating one water molecule between $73{ }^{\circ} \mathrm{C}$ and $199{ }^{\circ} \mathrm{C}$ (synthetic air) and between $65{ }^{\circ} \mathrm{C}$ and $203{ }^{\circ} \mathrm{C}\left(\mathrm{N}_{2}\right)$ with mass loss of $6.9 \%$ in both atmospheres. At this stage, two endothermic peaks were observed at $89.6{ }^{\circ} \mathrm{C}$ and $196{ }^{\circ} \mathrm{C}$ in both atmospheres. After the anhydrous formation, an exothermic peak around $211^{\circ} \mathrm{C}$ (synthetic air and $\mathrm{N}_{2}$ ) of low intensity is observed, which may be associated with a crystallization process. The decomposition of the ligand occurs in two distinct stages: between $200{ }^{\circ} \mathrm{C}$ and $450{ }^{\circ} \mathrm{C}$ (synthetic air) and between $206{ }^{\circ} \mathrm{C}$ and $440{ }^{\circ} \mathrm{C}\left(\mathrm{N}_{2}\right)$, both with formation of the $\mathrm{CuSO}_{4}$ intermediate $(\mathrm{Calc} .=$ $58.31 \%, \quad$ TG $=58.13 \%)$. In this stage endothermic DTA peaks are observed: $343{ }^{\circ} \mathrm{C}$, $420{ }^{\circ} \mathrm{C}$ and $436{ }^{\circ} \mathrm{C}$ (synthetic air) and $345^{\circ} \mathrm{C}, 412$ ${ }^{\circ} \mathrm{C}$ and $426{ }^{\circ} \mathrm{C}\left(\mathrm{N}_{2}\right)$. The $\mathrm{CuSO}_{4}$ intermediate remains stable over a wide temperature range: between $444{ }^{\circ} \mathrm{C}$ and $694{ }^{\circ} \mathrm{C}$ (synthetic air) and between $440{ }^{\circ} \mathrm{C}$ and $618{ }^{\circ} \mathrm{C}\left(\mathrm{N}_{2}\right)$. In this stage endothermic peaks are observed at $741{ }^{\circ} \mathrm{C}$ and 799 ${ }^{\circ} \mathrm{C}$ (synthetic air) and $718{ }^{\circ} \mathrm{C}$ and $773{ }^{\circ} \mathrm{C}\left(\mathrm{N}_{2}\right)$. The formation of the residue supposed $\mathrm{CuO}$ occurs at $810{ }^{\circ} \mathrm{C}$ (synthetic air) and $780{ }^{\circ} \mathrm{C}\left(\mathrm{N}_{2}\right)$. Under $\mathrm{N}_{2}$ atmosphere a new stage of mass loss appears, which begins at $840{ }^{\circ} \mathrm{C}$ and probably ends at temperatures above $900{ }^{\circ} \mathrm{C}$. The DTA profile of the beginning of this stage has endothermic characteristics, suggesting a $\mathrm{Cu}^{2+} \rightarrow \mathrm{Cu}^{+}$reduction process.

\section{$3.5 \mathrm{Zn}\left(\mathrm{NH}_{2} \mathrm{SO}_{3}\right)_{2} .3 \mathrm{H}_{2} \mathrm{O}$}

Dehydration $\mathrm{Zn}\left(\mathrm{NH}_{2} \mathrm{SO}_{3}\right)_{2} \cdot 3 \mathrm{H}_{2} \mathrm{O}$ occurs two overlapping steps, between $64{ }^{\circ} \mathrm{C}$ and $195{ }^{\circ} \mathrm{C}$ (synthetic air and $\mathrm{N}_{2}$ ), equivalent to the consecutive release of one and two water molecules, respectively, with losses of the order of $17 \%$, Endothermic peaks are observed at $97{ }^{\circ} \mathrm{C}$ and $163{ }^{\circ} \mathrm{C}$ (synthetic air and $\mathrm{N}_{2}$ ). After formation of the anhydrous compounds, an exothermic peak was observed around $202{ }^{\circ} \mathrm{C}$ (synthetic air and $\mathrm{N}_{2}$ ). The anhydrous compound remains stable between $190{ }^{\circ} \mathrm{C}$ and $295{ }^{\circ} \mathrm{C}$ (synthetic air) and $196{ }^{\circ} \mathrm{C}$ and $322{ }^{\circ} \mathrm{C}\left(\mathrm{N}_{2}\right)$. The decomposition of the ligand in synthetic air starts at $304{ }^{\circ} \mathrm{C}$, with endothermic peaks at $364{ }^{\circ} \mathrm{C}$ and $457{ }^{\circ} \mathrm{C}$ (synthetic air) and $364{ }^{\circ} \mathrm{C}$ and $465{ }^{\circ} \mathrm{C}\left(\mathrm{N}_{2}\right)$. This stage leads to the formation of intermediate $\mathrm{ZnSO}_{4}($ Calc. $=51.80 \%, \mathrm{TG}=52.40 \%)$, which remains stable over a wide temperature range of $467{ }^{\circ} \mathrm{C}$ to $688{ }^{\circ} \mathrm{C}$ (synthetic air) and $471{ }^{\circ} \mathrm{C}$ to 684 ${ }^{\circ} \mathrm{C}\left(\mathrm{N}_{2}\right)$. In a synthetic air atmosphere, the decomposition to $\mathrm{ZnO}$ occurs from $690{ }^{\circ} \mathrm{C}$ and ends at $913{ }^{\circ} \mathrm{C}$, presenting endothermic peaks at $804{ }^{\circ} \mathrm{C}$ and $900{ }^{\circ} \mathrm{C}$. In nitrogen atmosphere, residual oxide formation is not completed until $920^{\circ} \mathrm{C}$ and endothermic peaks are observed at 744 ${ }^{\circ} \mathrm{C}, 789^{\circ} \mathrm{C}$ and $912{ }^{\circ} \mathrm{C}$.

\section{Conclusions}

The main absorptions in the infrared: $\mathrm{vO}-\mathrm{H}$ $\left(3600-2700 \mathrm{~cm}^{-1}\right)$ in the salts; $v N-H(3400-3300$ $\left.\mathrm{cm}^{-1}\right)$ in amidosulfonic acid; vsS-O (1260-1140 $\left.\mathrm{cm}^{-1}\right)$ and vas $S-O\left(1040-1020 \mathrm{~cm}^{-1}\right)$ emphasize the differences between the spectra of the salts and of the amidosulfonic acid, evidence the bond to the metal suggesting that the coordination occurs by the sulphonic grouping.

The X-ray diffractograms indicate that the compounds were obtained with a certain crystallinity degree, showing no evidence of isomorphism. The compounds showed relatively low intensity reflections.

The thermoanalytical results (TG/DTA) allowed to establish the stoichiometry of the compounds as: $\mathrm{ML}_{2} \cdot \mathrm{xH}_{2} \mathrm{O}$, where $\mathrm{M}$ represents the metallic ions $\mathrm{Mn}^{2+}, \mathrm{Co}^{2+}, \mathrm{Ni}^{2+}, \mathrm{Cu}^{2+}$ and $\mathrm{Zn}^{2+}$; $\mathrm{L}$ represents the anion $\mathrm{NH}_{2} \mathrm{SO}_{3}^{-}$; $\mathrm{x}$ represents the number of water molecules, where $\mathrm{x}=4$ for $\mathrm{Mn}^{2+}$, $\mathrm{x}=3$ for $\mathrm{Co}^{2+}$; and $\mathrm{Zn}^{2+}, \mathrm{x}=2$ for $\mathrm{Ni}^{2+}$ and $\mathrm{x}=1$ for $\mathrm{Cu}^{2+}$. No significant differences were observed 
between the analysis carried out in synthetic air or nitrogen atmosphere, only the thermal decomposition of the ligand in synthetic air atmosphere occur at slightly lower temperatures that in a nitrogen atmosphere. For all compounds, the $\mathrm{MSO}_{4}$ stable intermediate was observed, which later decomposes to the respective oxide, that is: $\mathrm{Mn}_{3} \mathrm{O}_{4}, \mathrm{CoO}, \mathrm{NiO}, \mathrm{CuO}$ and $\mathrm{ZnO}$. In some samples the residual oxide is produced at temperatures above $950{ }^{\circ} \mathrm{C}$.

\section{Acknowledgments}

This research was supported by resources supplied by the Faculdade de Engenharia de Guaratinguetá (UNESP). The authors thank Prof. Dr. Edson Cocchieri Botelho (DMT-FEG-UNESP) for TGDTA measurements, Prof. Dr. Sergio Francisco dos Santos (DMT-FEG-UNESP) for X-ray diffractometry, Prof. Dr. Konstantin Georgiev Kostov (DFI-FEG-UNESP) for FTIR measurements.

\section{References}

[1] Index, M., Centennial edition, Merck \& Co. Inc. Rahway, 1989.

[2] Kamal, A., Babu, K. S., Hussaini, S. M. A., Srikanth, P. S., Balakrishna, M., Alarifi, A., Sulfamic acid: an efficient and recyclable solid acid catalyst for the synthesis of 4,5-dihydropyrrolo[1,2-a]quinoxalines, Tetrahedron Letters 56 (31) (2015) 4619-4622. https://doi.org/10.1016/j.tetlet.2015.06.006.

[3] Maksin, V. I., Standritchuk, O. Z., Solubility diagrams of the systems nickel sulfamate-water and cobalt sulfamate-water, Russian Journal of Applied

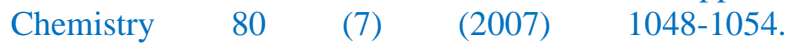
https://doi.org/10.1134/S1070427207070063.

[4] Budurov, S, Tzolova, G., Thermogravimetrische Untersuchung der thermischen Zersetzung von Amidosulfonaten einwertiger metalle, Thermochimica

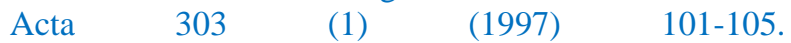
https://doi.org/10.1016/S0040-6031(97)00256-6.

[5] Budurov, S., Tzolova, G., Bohatý, L., New structural phase transitions in potassium and sodium amidosulfonates, Thermochimica Acta 307 (1) (1997) 91-96. https://doi.org/10.1016/S0040-6031(97)003602.

[6] Thege, I. K., DSC investigation of the thermal behaviour of $\left(\mathrm{NH}_{4}\right)_{2} \mathrm{SO}_{4}, \mathrm{NH}_{4} \mathrm{HSO}_{4}$ and $\mathrm{NH}_{4} \mathrm{NH}_{2} \mathrm{SO}_{3}$,
Thermochimica Acta 60 (2) (1983) 149-159. https://doi.org/10.1016/0040-6031(83)80265-2.

[7] Stade, J., Held, P., Bohatý, L., Crystal Growth, Crystal Structure and Physical Properties of Lithium Sulfamate $\mathrm{Li}\left[\mathrm{NH}_{2} \mathrm{SO}_{3}\right]$, Crystal Research and Technology $36 \quad$ (4-5) (2001) 347-360. https://doi.org/10.1002/15214079(200106)36:4/5\%3C347::AIDCRAT347\%3E3.0.CO;2-Q.

[8] Haussühl, E., Haussühl, S., Elastic properties of sulfamic acid and sulfamates of $\mathrm{Li}, \mathrm{Na}, \mathrm{K}, \mathrm{Rb}, \mathrm{Cs}, \mathrm{Tl}$, $\mathrm{NH}_{4}, \mathrm{C}\left(\mathrm{NH}_{2}\right)_{3}$ and $\left(\mathrm{CH}_{3}\right)_{3} \mathrm{NCH}_{2} \mathrm{COOH}$, Zeitschrift Für

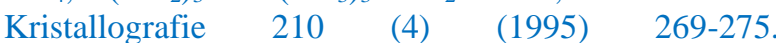
https://doi.org/10.1524/zkri.1995.210.4.269.

[9] Shimizau, G. K. H., Enright, G. D., Ratclife, C. I., Rego, G. S., Reid, J. L., Ripmeester, J. A., Silver Sulfonates: An Unexplored Class of Layered Solids, Chemistry of Materials 10 (11) (1998) 3282-3283. https://doi.org/10.1021/cm980409b.

[10] Shubnell, A. J., Kosnic, E. J., Squattrito, P. J., Structures of layered metal sulfonate salts: trends in coordination behavior of alkali, alkaline earth and transition metals, Inorganica Chimica Acta 216 (1-2) (1994) 102-112. https://doi.org/10.1016/00201693(93)03700-K.

[11] Gunderman, B. J., Squatrito, P. J., Synthesis and Structures of Potassium and Rubidium Arenesulfonates, Journal Logo 33 (13) (1994) 2924 2931. https://doi.org/10.1021/ic00091a035.

[12] Kosnic, E. J., McClymont, E. L., Hodder, R. A., Squattrito, P. J., Synthesis and structures of layered metal sulfonate salts, Inorganica Chimica Acta 201 (2) (1992) 143-151. https://doi.org/10.1016/S00201693(00)85325-6.

[13] Jaishree, D., Kanchana, G., Kesavasamy, R., Investigations on Growth, Optical and Thermal Properties of Sulphamic Acid Single Crystals, Investigations on Growth, Optical and Thermal Properties of Sulphamic Acid Single Crystals 2014 (2014) 950467. https://doi.org/10.1155/2014/950467.

[14] Brahmaji, B., Rajyalakshmi, S., Rao, T. K. V., Valluru S. R., Basha, S. K. E., Satyakamal, C., Veeraiah, V., Rao, K. R., Tb ${ }^{3+}$ added sulfamic acid single crystals with optimal photoluminescence properties for opto-electric devices, Journal of Science: Advanced Materials and Devices 3 (1) (2018) 68-76. https://doi.org/10.1016/j.jsamd.2017.12.002.

[15] Wickleder, M. S., Syntheses, crystal structures, and thermal behavior of the rare earth amidosulfates 
$\mathrm{M}\left(\mathrm{NH}_{2} \mathrm{SO}_{3}\right)_{3} \cdot 2 \mathrm{H}_{2} \mathrm{O}(\mathrm{M}=\mathrm{Pr}, \mathrm{Nd}, \mathrm{Sm})$, Journal of Alloys and Compounds 303-304 (2000) 445-453. https://doi.org/10.1016/S0925-8388(00)00624-1.

[16] Luiz, J. M., Nunes, R. S., Matos, J. R., Síntese, caracterização e comportamento térmico de amidossulfonatos de terras raras, Quimica Nova 36 (3) (2013) 426-430. https://doi.org/10.1590/S010040422013000300013. 